\title{
Implementing Teacher Races Game (TRG) to Improve Students' Grammar Skill Simple Past Tense
}

\author{
Ratna Ayu Pawestri Kusuma Dewi \\ (Teknik Mesin Alat Berat, Politeknik Negeri Madura), Indonesia \\ ratnaayupkd@poltera.ac.id
}

\begin{abstract}
Vocabulary and grammar are the most essential components of all use of language as they have to be taught to the language learner to support to the development of the four skills, especially for writing skills. Unfortunately, Grammar has been believed as the most terrific problem for most of adolescence learners. They were terrific to construct wrong order of sentence (grammar) and this problem will effect on creating ideas in writing. This study was an experimental quantitative study which needs two subject groups experimental and control group. The population chosen is one state junior high school in Surabaya. The simple random samples used; and VIII $\mathrm{C}$ as an experimental class and VIII A as a control class. The pre-test and post-test were given to both of the groups. Tests consist of tryout, pre-test and post-test that were used to collect the data. According to the collected data, the researcher made statistical calculation by using t-test and analysis to answer the research question. $\mathrm{T}_{\text {test }}$ results were examined to know the comparison of experimental and control groups' mean. The ttest of pre-test and post-test scores of

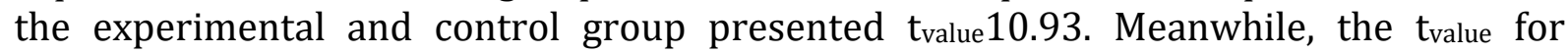
rejecting the null hypothesis with $\mathrm{df} 50$ at $\mathrm{t} .05$ was 2.009. It indicated that $\mathrm{t}_{\text {value }}>$ than $\mathrm{t}_{\mathrm{value}}$ (10.93>2.009) so that it can be concluded that null hypothesis (Ho) is rejected and the alternative hypothesis ( $\mathrm{Ha}$ ) is accepted. This study decide that there is a significant difference in scores of grammar simple past tense test between the eighth graders who are taught using teacher races game and those who are not taught in that way. It can be proved by the test calculation result, 10.93. It stated that teacher races game is able to improve students' score of grammar mastery simple past tense. Moreover, the ttest result which is higher than $\mathrm{t}$-table (2.009) confirms that the null hypothesis is rejected (Ho), and the alternative hypothesis (Ha) is accurately accepted. For further suggestions, the teachers, especially English teachers, are expected to use appropriate techniques or methods to teach grammar and build an interesting atmosphere in the classroom in order to make students enjoy in their learning activity.
\end{abstract}

Keywords: Game, Teacher Races Game (TRG), Writing, Recount Text, Grammar, Simple Past Tense (SPT)

\begin{tabular}{ll}
\hline Article History & Received : August $7^{\text {th }} 2020$ \\
& Revision : October $11^{\text {th }} 2020$ \\
& Publication : Dec $30^{\text {th }} 2020$ \\
\hline
\end{tabular}


Volume 4 Number 2 December 2020

\section{INTRODUCTION}

Writing takes an important role for English Foreign Learner (EFL) in the real language learning. According to Chastain (1979), having ability of writing nowadays in society and school are very important, and should be the essential objectives of language study. There are four basics English language skills which have to be emphasized in learning and teaching language. They are listening, speaking, reading and writing skills. These four skills cannot be separated each other.

It means we should integrate them in learning and teaching activity. Regrettably, people commonly ignore writing skill. They often think that the main important skill that should be mastered is only speaking skill. On the other hand, mastering writing skill is also essential to do since mastering writing is not easy. Writing skill is still considered as the most difficult skill because to be able to write something, writer do not only have to generating and organizing ideas in their mind but also have to be able translating ideas into readable text. Richard and Renandya, (2002:303).

Alongside that statements above the reality happened around us, in doing writing activity; some of students are still difficult to tell their idea into a paragraph, and the others find difficulty in create even a sentence. This problem occurs because they think that writing is extremely difficult as they have to be able to comprehend some of language competence at the same time while they are writing. In this case, the language competences are vocabularies and grammars.

Richard (1987:45) uttered that vocabulary and grammar are the most essential components of all use of language as they have to be taught to the language learner to support to the development of the four skills, especially for writing skills. Unfortunately, most of the language learners find various obstacles when they want to make sentences with has grammatically correct. Grammar has been believed as the most terrific problem for most of adolescence learners since they hate grammar. They were terrific to construct wrong order of sentence (grammar) and this problem will effect on creating ideas in writing Brown (2001:342). This case indicates that grammar should be mastered by English learners especially students who want to create ideas in writing.

Eighth graders are expected to be able to understand and produced in the form of descriptive and recount text in first semester and recount text, and narrative text for the second semester. Recount occurs twice in both first and second semester. It indicates that recount becomes one of the essential texts that should be mastered for eight grade students of junior high school. Due to those problems, actually the teacher as an educator must be able to improve the students' ability in using and applying grammar which is in line with the texts -recount texts.

According to Priyana (2008:61) one of the language features of recount texts is simple past tense. Therefore, in this research, the researcher decides simple past tense as a material to be given to the eight graders as in composing recount text, they need to comprehend deeply in mastering simple past tense. Simple past tense is one kind of 
tense which concern in indicates an activity or situation began and ended at a particular time in the past. Considering that teaching grammar to adolescence learners is not an easy job to do, hence the researcher tries to use an innovative way to teach grammar. She teaches grammar simple past tense (SPT) through game.

Hadfield (2005) uttered the definition of games. Games are defined as an activity that consisted of some sequence of rules, aimed (goal), and a bunch of elements of fun. A good English teacher who wants make their pupils enjoy the learning activity in the class must apply game as a technique to teach the lesson. Since by applying game in the class, the teacher can balance the serious study of English with the more entertaining activities that they think their students need Harmer (1998:8). Through games, teacher can boost students' motivation to learn and decrease their boredom. A game is also believed as a structural and semi-structural activity which offers enjoyment that could be applied for all skills Wright (1983:1).

Good games have to be very flexible and can be used for teaching any aspects of the language and also can be used for teaching any aspects of the language. Moreover, he also stated that a good game also must not be too difficult to prepare and not spend so much money. In line with the criteria of a good game that has been stated, in this study, the researcher used a game which can fulfill the criteria; and can be used effectively to teach grammar - SPT to the eighth graders. The game named teacher races game (TRG).

It has been proved that $T R G$ is a game which is suitable to teach eighth graders since in playing this game the motoric activity is very dominant Santrock (1995:299). He stated that the students in the middle ages- Junior high school year - actually have not been physically mature yet. They will easily get bored and stuck if they just keep sit down and focus to the teacher explanation. Hence, doing motoric activity in a teaching and learning is needed. By doing it, pupils will not easily get bored; and as a result, they will be able to comprehend the lesson more.

$T R G$ can be an alternative way to improve students' grammar SPT mastery. Smith (2008) stated although in practicing this game the pupils will need extra energy to run more and more to get the right answer, but it still gives chance to the students to work cooperatively in getting the right answer. It means, at the same time while they do drilling, they memorize the lesson by themselves. So, it is believed by doing this game will be able to improve the students' grammar SPT mastery.

As Smith (2008) uttered, TRG has several benefits. First by doing this game, it also teaches the pupils how to work cooperatively in a group is. They will learn about time management, divide job and take responsibility in their own group. Second, in conducting this game, the motoric activity is very dominant. So, they will not easily get bored and stuck with the teacher explanation. Third, in this game students also must run again and again to get the right answer, at the same time, they also do drilling and memorize the lesson by themselves. Overall, based on all the reason, the research attempts to conducts research that wants to find out the effectiveness of using game-Teacher Races Game 
$(T R G)$ to teach simple past tense (SPT) in recount text which conducted in one of the state junior high schools in Surabaya.

Therefore, this research question is: "Is there any significant difference in scores of grammar simple past tense in recount texts between the eighth graders who are taught using teacher races games and those who are not taught in that way?" As a result, this study aims to find out whether there is a significant difference in scores of grammar simple past tense in recount texts between the eighth graders who are taught using teacher races game and those who are not taught in that way.

Derived from the formulated research problems, hypotheses that can be drawn in this research are two hypotheses: 1) they are Null Hypotheses (Ho) that there is no a significance different of eight graders' scores of grammar SPT test in Recount Text between students who are taught using game, TRG, and who are not, and 2) Alternative Hypotheses (Ha) that there is a significance different eight graders' scores of grammar $S P T$ test in Recount Text between students who are taught using game, $T R G$, and who are not.

The significance of the study are: 1) For Students, it can motivate them to learn grammar, especially in comprehend grammar. Students who are reluctant to learn SPT need to be encouraged and given motivation and fun atmosphere in learning tenses, 2) For Teacher, TRG can be used as an innovative way in teaching grammar when the conventional way commonly makes students get bored easily and less motivated., 3) For School, it can be used as a tool to solve the real problem which is commonly happened in teaching and learning activity in junior high school students.

\section{LITERATURE REVIEW \\ Recount Text}

According to Competence Based 2006, Recount Text is a kind of text dealing with the experiences happened in the past and focuses on a sequence of events related to the occasion which the purpose is to informing or entertaining the reader (Standard Competence, 2006:9). Recount text also has expression of attitude and feeling, and usually made by the writer about the events. Furthermore another scientist also supports this idea, Anderson (1997:48) stated that recount is a kind of text that retells the reader about the writer's past events. Since recount text is tell the reader about the writer's experiences which happened in the past, hence the form of simple past tense is commonly used in writing the recount text. The following is a model of recount text.

\section{My Holiday in Flores}




\begin{tabular}{|l|l|}
\hline Orientation & $\begin{array}{l}\text { I went to Flores last month. I went there to visit Australian Volunteer } \\
\text { English teachers in Maumere, Ende and Bajawa. As a result, I also } \\
\text { enjoyed the beauty of the island. }\end{array}$ \\
\hline Event 1 & $\begin{array}{l}\text { I started my first day in Manumere with Jo Keating. After visiting } \\
\text { several schools in the city, we took an amazing journey over the } \\
\text { mountains to the south coast. We visited a new junior high school there. }\end{array}$ \\
\hline Event 2 & $\begin{array}{l}\text { Then, I traveled to Ende to meet Sharon Kidman. Ende has great and } \\
\text { outstanding market with a lovely selection of traditional woven ikat } \\
\text { cloth, and great seafood. }\end{array}$ \\
\hline Event 3 & $\begin{array}{l}\text { My next trip was to Detusoko. It is mountain village. I went there with } \\
\text { Ginny Edwars. Detusoko is not far from Mount Kalimutu. We woke up at } \\
4 \text { am to see the three different colored lakes at dawn. It was truly } \\
\text { inspiring }\end{array}$ \\
\hline Event 4 & $\begin{array}{l}\text { My final trip was to Bajawa. It is a small town high in the } \\
\text { mountains. It was a very cold place. }\end{array}$ \\
\hline Reorientation & $\begin{array}{l}\text { Yet my trip was fun and memorable. I would like to go back to } \\
\text { Flores one day. }\end{array}$ \\
\hline
\end{tabular}

\section{The Teaching Grammar}

The term grammar has many definitions. For the first, grammar means a system of rules governing the conventional arrangement and relationship of words in a sentence. According to Brown (1994:347) grammar tell us about the way of constructing a sentence; word order, verb and noun systems, modifiers, phrases, clauses, etc. Shortly, we can conclude that grammar is a "pack" of rules by which people are speaking and writing. Furthermore, Penny Ur (1988:4) explained more about the essential of teaching grammar.

According to Depdiknas, teaching grammar for Indonesia learners must be taught implicitly, means not directly in teaching and learning activity, but basically grammar is necessary for communication. Richard (1987:45) states that vocabulary and grammar is essential components of all use of language. Since they are taught to the learner to support to the development of the four skills, especially for writing skills. Grammar has been believed as the most terrific problem for most of adolescence learners in creating their ideas in writing. They were terrific to construct wrong order of sentence (grammar). This case indicates that grammar should be mastered by English learners especially students who want to create ideas in writing. Mastering grammar is important because words without being arranged into right order means nothing.

\section{Simple Past Tense (SPT)}


It has been stated before that in writing recount text; we have to consider two important aspects. They are the generic structure and language feature of recount text. One character of recount text language feature according to Priyana, Irjayanti, \& Renitasari (2008:9), simple past tense is one kind of grammar which must be mastered by the learner in order to be able compose recount text.

Hence, $S P T$ is a suitable material to be given to eight graders students in order to help to compose recount text easier. They need to comprehend deeply in mastering simple past tense. Moreover, the term of simple past tense itself is a kind of tense which concern in indicates an activity or situation began and ended at a particular time in the past.

There are some patterns of SPT. The patterns are active simple past tense and passive simple past tense. Moreover, the active simple past tense itself is divided into two branches. First pattern is verbal sentences which and nominal sentences. Here are the briefly explanation of verbal and nominal sentences for active simple past tense

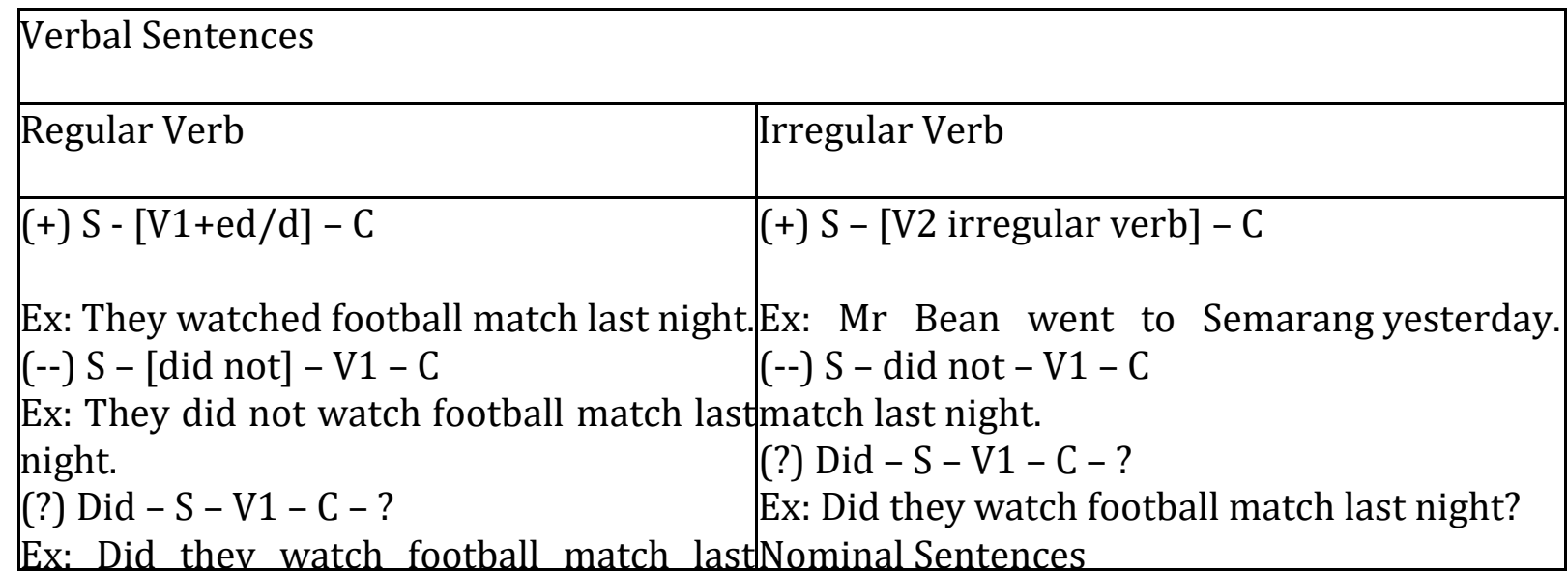


Volume 4 Number 2 December 2020

\begin{tabular}{|l|l|}
\hline \multicolumn{2}{|l|}{ Nominal Sentences } \\
\hline Singular Pronoun & Plural Pronoun \\
\hline $\begin{array}{l}\text { (I, He, She, It, [name of person, place, } \\
\text { thing, which the quantity is not more } \\
\text { than 1] ) }\end{array}$ & $\begin{array}{l}\text { (You, We, They, [name of people, } \\
\text { than 1] ) }\end{array}$ \\
$\begin{array}{l}\text { (+) S - was - non.verb - C } \\
\text { Ex: She was in Bali last week. }\end{array}$ & $\begin{array}{l}\text { (+) S - were -non.verb - C } \\
\text { Ex: They were in front of me an hour ago. } \\
(--) S-\text { (were + not) -non.verb - C }\end{array}$ \\
$\begin{array}{l}(--) \text { S - (was+not) - non.verb - C Ex: She } \\
\text { was not in Bali last week. }\end{array}$ & $\begin{array}{l}\text { Ex: They were not in front of me one hour } \\
\text { ago }\end{array}$ \\
$\begin{array}{l}\text { (?) Was - S - non.verb -C-? Ex: Was she } \\
\text { in Bali last week.? }\end{array}$ & $\begin{array}{l}\text { ?) Were - S - non. verb -C -? } \\
\text { Ex: Were they in front of you one hour ago? }\end{array}$ \\
\hline
\end{tabular}




\section{Games in Language Learning}

Many teachers just use conventional way to teach grammar to their pupils. As a result, many of them are really bored, lack their enthusiasms. To prevent such kinds of situations, teachers have to be more creative. They can use another way to teach grammar to their students. For instance use game as an alternative and innovative way to teach pupils about grammar.

Games are really an attractive way because they are fun, the pleasant relaxed atmosphere fostered by the games has proven to be efficient learning. (Johnson and Johnson, 1975: 75). Moreover, another scientific also stated some advantages of games, they are:

1. Games are a welcome break from the usual routine of the language class.

2. They are motivating and challenging.

3. Learning a language requires a great deal of effort. Games help students to make and sustain the effort of learning.

4. Games provide language practice in the various skills- speaking, writing, listening and reading.

5. They encourage students to interact and communicate.

6. They create a meaningful context for language use.

$\operatorname{Kim}(1995)$.

Though, old belief said that game is often time consuming, but actually through game, teacher can do some skills at the same time, not only one skill. Hence, this means that game is not time consuming. Ersoz (2002) "Games can be used to give practice in all language skills and be used to practice many types of communication".

\section{The Teacher Races Game (TRG)}

$T R G$ is one of the name of game which is commonly used in some language courses, such as KELT English course. In this game, the pupils will work in groups of five to six. Each group has to answer the questions that have been given before to the teacher. Each group must send one of their delegations to approach the teacher. The teacher is waiting outside the classroom. While approaching to the teacher to answer the question, the delegation is not allowed to bring out the paper with them. They must memorize the answer. The teacher decide whether the pupil get the point or not based on the accuracy and fluency of the students' answer. If the answer is not proper yet, teacher will say "Sorry, your answer is not proper yet, go back to your group, discuss and repair your answer". However, if the answer is proper, the teacher will give star as a sign that the group has already got one point.

\section{The rules of Teacher Races Game}


1. Choose a proper simple past tense question which is suitable for the eighth graders. The question must not be too difficult and easy.

2. Copy the paper question up to member quantity.

3. Explain that each group must send their delegation to the teacher to answer the question in paper question.

4. The teacher wait outside the classroom

5. After the group has discussed the suitable answer for the question, then they have to send their delegation to the teacher.

6. Teacher decide whether the answer of the delegation from each group proper or not. Proper means they can change the sentence which has wrong verb into the right sentence, accurately and fluently as she can.

7. If the delegation gives the right answer to the teacher, she will get 'star' equal with one point; however, if she gives the wrong answer, she must go back to her group and change with another member.

8. The winner group is the group which get more 'star' and have fulfill the wrong sentence in paper question into the right sentence.

9. In the end of the game, teacher asks the students who are giving the right answer to write down the full right sentence in the blackboard.

\section{METHOD}

The researcher used experimental research as her research design. In which, the term of experimental research itself means determine the cause and effect and compare two groups (Ari Kunto, 2006:86).

Thus, in this research, the researcher aimed to find out whether there was a significant difference in scores of grammar simple past tense test between the eighth graders who are taught using $T R G$ and those who were not taught in that way. Consequently, the researcher conducted two groups or classes in this research. They were experimental and control group.

The researcher applied simple random sampling technique to find out two classes as samples. Firstly, the researcher captured experimental and control groups. Then, she administered pre-test to the both students of experimental and control groups. The aimed of the pre-test was to measure the students' grammar simple past tense mastery before they got treatment from the researcher.

After pre-test had conducted, the treatment was given to the experimental group. The treatment in this research was using TRG to teach SPT. However, in control group, the researcher only applied conventional way to teach the class. Both of them did in three meetings. After the treatments were given to the experimental group in three meetings, later a post- test was administered to both groups.

Table 3.2

\begin{tabular}{|c|c|c|c|}
\hline Group & Pre-Test & Treatment & Post-Test \\
\hline
\end{tabular}




\begin{tabular}{|c|c|c|c|}
\hline $\mathrm{E}$ & $\mathrm{Y} 1$ & $\mathrm{X}$ & $\mathrm{Y} 2$ \\
\hline $\mathrm{C}$ & $\mathrm{Y} 1$ & - & $\mathrm{Y} 2$ \\
\hline
\end{tabular}

Where :

E : The experimental group was a group who were taught simple past tense using Teacher races game

C : The control group was a group who were not taught simple past tense using Teacher races game

Y1 : The pre-test administered before treatment

X : The treatment

Y2 : The post-test administered after treatment

The researcher examined two kinds of variables in order to know and compare the effectiveness of using teacher races game to teach SPT in recount text. They are: 1) Independent variable is variable that can affect another variable (dependent variable) as well as be able to be manipulated by the investigators (Ary et. Al., 1990:31). Mc Millan (1992:82) also stated that independent variable also often called as experimental treatment variable. Hence, the independent variable in this research was using $T R G, 2$ ). Dependent Variable is the variable that is affected by independent variable which the effect of the manipulation is observed. Hence, the independent variable in this research was the eight graders' score of grammar SPT test.

The population of this research was the eighth graders students. There are ten classes of eighth graders. They are VIII A, VIII B, VIII C, VIII D, VIII E, VIII F, VIII G, VIII, VIII I, and VIIIJ . By using the random sampling, in the end the researcher got VIII $\mathrm{C}$ and VIII $A$ as the sample of the research. The concept of simple random sampling itself is all the members of the population have an equal and independent change and independent change of being included in the sample (Ary et. Al., 1990:141). Moreover, to decide which class belongs to experimental and control group, the researcher used simple random assignment to solve the problem. Finally, the result is stated below:

1. Experimental group, a group who were taught simple past tense using Teacher races game, belongs to VIII C.

2. Control Group, a group who were not taught simple past tense using Teacher races game belongs to VIII A.

An instrument is a device to get the data. The researcher investigated whether using $T R G$ to improve eight graders' score of grammar SPT in recount text or not. For accomplishing the objective, she needed students' score as the data. The one instrument that used in this study was test.

Test is a kind of tool or device for supports learning process and motivates students. Heaton (1998) utter that actually teaching activity and testing are two things that closely correlated and cannot be splited up one to another.

In this research, the test consisted of 50 objective test items, which were divided into three section The first section of the test was consisted of 20 multiple choice items with score maximum was 20 . Next, is the second section which was consisted of 20 items with maximum score is 40 , in this section students were asked to change the incorrect verb in the brackets into the correct form of simple past tense in recount text. The last 
section was the third section, consisted of 10 numbers items with score 40 , in third section students were asked to change simple present tense form into simple past tense form.

As stated above that in conducting this research, the researcher used one instrument that was test. The researcher administered the test into three times. All of them were actually the same text. Despite they were actually equal, but the function was different. They were divided into three parts. First was called try out test. Second test was pre-test. The last part was post-test.

The researcher used content validity because it depends on a careful analysis of the language being tested and the particular course objectives (Heaton, 1975:153). The items of the text should be in line with the subject matter content. Since all of the test items in grammar mastery simple past tense test were derived from the government curriculum in Indonesia and taken from the book which have been chosen by our government such as scaffolding VIII, English in Focus VIII, and Bahasa Inggris VIII, thus they were suitable with the students' proficiency. In this research, the test was intended to measure the students' accomplishment in learning simple past tense.

A test was called reliable if the result of the test was constant, not so different. Reliability of measuring instrument is the degree of consistency with which it measures whatever it is measuring (Ary, 1985:225). The goal of developing reliable test is to minimize the influence of chance or other variables unrelated to the intent of the measure (Mc Millan and Schumacher, 1993:227). Reliability of the test in this study was measured in term of internal concistency which has three common types: (1) split half, (2) kuder Richardson - kr21, and (3) cronbach alpha. Finally, the researcher was measured the tryout test using kuder Richardson - kr21 formula as it has simple administration and easy to apply in classroom achieve test (Arikunto, 2002:168). The formula used as follow (Arikunto, 2002:168):

$$
1 \pi \quad=\frac{N}{N-1}\left(1-\frac{(m N-) m}{N x S B}\right.
$$

Where : $\quad$ Table 3.3

$\mathrm{N}$ : The number of test items

$\mathrm{m}$ : The mean scores

Sd Standard deviation of try out test

First, table Kr21 (Appendix 1) was used to analyze the reliability of the test. The researcher got the scores from the students who were administered test and did not belong to either experimental or control group. Then, she counted the standard deviation of the test. Next, put the scores into $\mathrm{Kr} 21$ formula. The result of $\mathrm{Kr} 21$ formula was consulted to table of scale reliability

$$
\begin{aligned}
1 \pi & =\frac{N}{N-1}\left(1-\frac{(m N-) m}{N x S D^{2}}\right. \\
& =\frac{50}{50-1}-\cdot \frac{(27356-2) 73}{5 C X 114} \frac{7}{2} \\
& =1.02(1-0.095)
\end{aligned}
$$


Reliability Interpretation

\begin{tabular}{|cl|}
\hline $.80-1.00$ & $:$ Very Good \\
$.70-.80$ & $:$ Good \\
$.60-.70$ & $:$ Low \\
$.50-.60$ & $:$ Very Low \\
Bellow .50 & $:$ Bad \\
\hline
\end{tabular}

The result of the reliability of the try out test was 0.9231 . It could be seen on the table that the test score was in the very good reliability level. It assumed that the test was very reliable.

50

Good $\quad \frac{16 \times}{50} 100 \%=38 \%$

Excellent : $\underline{6 \mathrm{X}} 100 \%=12 \%$

50

The data was collected from the test (tryout, pre-test and post-test). To measure the validity and reliability of the test, tryout was given to students. The test is in the form of multiple choices that consist of 50 questions. The test was administered during 80 minutes. The data will be presented in the quantitative manner because it is experimental research. Since the test is valid and reliable, the test will be given to both groups (experimental and control) as the pre-test. The pre-test was done to know the students' grammar SPT mastery before treatment was held.

The first treatment was done for the experimental class. The teacher introduced the topic that was about "Holiday in Kupang" a recount short story. After that teacher explained to them about the organization of recount text, next, it was time to teach them about $S P T$ verbal sentence. The pattern of $S P T$ verbal sentence was given to them. Moreover, to improve the ability of students' grammar SPT mastery more, she used TRG.

The second treatment for the experimental class. The teacher introduced the topic that was about recount texts more. After that teacher explained to them about the 
organization of recount text, next, it was time to teach them about simple past tense nominal sentence. The pattern of SPT nominal sentence was given to them. Moreover, to improve the ability of students' grammar SPT mastery more, she used $T R G$.

The third treatment was done for the experimental class. The teacher introduced the topic that was about recount texts again. After that teacher explained to them about the organization of recount text, next, it was time to review them about SPT verbal sentence and nominal sentence.

After the researcher conducted special treatment for experimental class for three meetings. However, in another class, she only teaches in conventional way. The last, the researcher gives post-test to both experimental and control group in order to get result. After collecting the data of pre-test and post-test from experimental and control group, the researcher analyzed it by using statistical calculation.

As soon as the researcher had collected the data from the students' pre-test and post-test score, the researcher should analyze it immediately. In this session, the researcher decided to analyze it quantitatively by using T-test formula to answer whether the hypothesis can be confirmed or rejected. Furthermore, by using this technique the researcher also could be able to get some indicators of significant different in mean between the experimental and control group.

Here is the steps to get the significance result

1. Tabulating the scores from pre-test and post-test.

2. Determining mean.

$$
\begin{aligned}
& \mathrm{X}=\sum \mathrm{X} N \\
& \text { Where: } \\
& \mathrm{X}=\text { mean } \\
& \sum \mathrm{X}=\text { the sum of students' scores } \\
& \mathrm{N}=\text { the number of observations }
\end{aligned}
$$

3. Determining Standard Deviation.

$$
\begin{aligned}
& \mathrm{S}=. \sqrt{\frac{\sum x^{2}}{N^{2}}} \\
& \mathrm{~S}=\text { standard deviation } \\
& \begin{array}{l}
\sum=\text { the sum of the squared score } \\
x^{2}
\end{array} \\
& \mathrm{X}^{2}=\text { the mean of the distribution } \\
& \mathrm{N}=\text { the number of observations }
\end{aligned}
$$

4. Determining Standard error of the differences. 
$\mathrm{S}_{\mathrm{Dx}}=\mid \overline{\frac{N_{1} S_{1}^{1}+N_{2} S_{2}^{2}}{N_{1}+N_{2}^{2}-2}}\left(\frac{1}{N_{1}}\right) \frac{1}{N_{2}}$

$\mathrm{S}_{\mathrm{Dx}}=$ standard error of the difference

$\mathrm{S}_{1}=$ the standard deviation of the first sample

$\mathrm{S}_{2}=$ the standard deviation of the second sample

$\mathrm{N}_{1}$ and $\mathrm{N}_{2}=$ the sizes of the respective sample

5. Determining degree of the freedom.

$$
\mathrm{N}-2
$$

6. Computing t-test.

$$
\mathrm{t} \quad=\frac{\bar{X} \bar{X}_{2}}{S_{D_{1}}}
$$

7. Where:

$$
\begin{aligned}
& \text { Where: } \\
& \mathrm{t} \quad=\mathrm{t}-\text { value } \\
& \overline{X_{1}} \quad=\text { Mean of Experimental group } \\
& \overline{X_{2}} \quad=\text { Mean of Control group } \\
& S_{D_{-}} \quad=\text { Standard error of difference }
\end{aligned}
$$

8. The calculation of T-test is used to compare two means to see the level of significance for rejecting the null hypothesis (McMillan, 1992:197). Afterward if the result $t_{v a l u e}>$ to. 5 indicates that there is a significant difference. A significance for rejecting the null hypothesis (McMillan, 1992:197).

9. Afterward if the result $t$-value $>$ t0.5 indicates that there is a significant difference.

\section{RESULTS AND DISCUSSION}

This research was conducted to know whether there is significant difference in scores of grammar Simple Past Tense test between the eighth graders who are taught using TRG and those who are not taught in that way.

The researcher presents the analysis the scores of experimental and control group. The data were taken from the test that was administered twice, they were pre-test and post-test. The pre-test was done before the treatment. On the other hand the post-test was done after the treatment. Therefore, the analysis of the data focused on each test and the correlation of the two. The experimental and control group consisted of 26 students. 
To know the effectiveness of $T R G$, the researcher used t- test formula. Before using that formula, first researcher calculate the means for each group. To know the significance, the researcher compared $t$-value with $t$-table. If $t$-value is higher than $t$-table, it means that there is a significant difference. On the other hand, if $t$-value is lower than $t$ table, it means that there is no significant difference.

Furthermore, before the pre-test was given to both experimental and control group, the researcher administered try out test.

\section{Scores of Try Out Test}

Essentially the aim of the try out test is to measure the validity and the reliability of the test items. Hence, it was given before the pre-test. As soon as conducting try out test, the researcher receive the data in the form of numbers. The researcher calculated the data to find the means score. The means score of the try out test was 27.307. After that, the researcher measured the validity of the test by using content validity. The researcher used KR-21 formula in measuring the reliability of the tryout test. The result of the calculation showed that the reliability of try out test was 0.923 . It means that the test had good reliability.

\section{The Significant Difference of Pre-test Scores and Means of the Experimental and Control Group}

To help find out the mean scores of both two groups, the researcher made a table below, where mean is gained by dividing the scores by the number of the subject $(N)$ :

\section{Table 1}

The Pretest Means of the Experimental and Control Group

\begin{tabular}{|c|c|c|c|}
\hline Group & Scores & N & Mean \\
\hline Experimental & 1545 & 26 & 59.42 \\
\hline Control & 1585 & 26 & 60.96 \\
\hline
\end{tabular}

From the table above, the mean of experimental and control group is not too different. Thus, it means both groups have almost the same ability in grammar simple past tense mastery.

Table 2

Significant Differences of Pre-test Scores of the Experimental and Control Group

\begin{tabular}{|c|c|c|c|c|c|}
\hline Group & $\mathbf{N}$ & Pre-test & Sd. & t-value & t-table \\
\hline Experimental & 26 & 59.42 & \multirow{2}{*}{3.02} & -0.51 & 2.009 \\
\hline Control & 26 & 60.96 & & & \\
\hline
\end{tabular}


Based on the table 2 above, the t-value was compared with t-table with level of significance of .05 and degree of freedom $50(26+26-2)$. From the data above, it can be seen that $t$-value is lower than $t$-table. It means that there is no significant difference of the pre-test scores between experimental and control group. So, it can be said that before the treatment, the experimental and control group have equal ability.

\section{The Significant Difference of Post-test Scores and Means of the Experimental and Control Group}

After the treatment was given for three times to the experimental group, the researcher gave both experimental and control group a post-test. The purpose of this test is that to know whether the treatment could improve students' grammar simple past tense mastery or not. The calculation of means from post-test of both experimental and control group was calculated. Here is the table so see the difference:

\section{Table 3}

\section{The Post-test Means of the Experimental and Control Group}

\begin{tabular}{|c|c|c|c|}
\hline Group & Scores & N & Mean \\
\hline Experimental & 2319 & 26 & 89.19 \\
\hline Control & 1626 & 26 & 62.54 \\
\hline
\end{tabular}

From the table above, it can be seen that the score of experimental and control group increases after given the treatment. Moreover, the post- test score of experimental group was higher than control group. Then, researcher calculated the two means of post-test by using t-test formula to know the significant difference between these two means.

Table 4

\section{Significant Differences of Post-test Scores of the Experimental and Control Group}

\begin{tabular}{|c|c|c|c|c|c|}
\hline Group & N & Post-test & Sd. & t-value & t-table \\
\hline Experimental & 26 & 89.19 & \multirow{2}{*}{2.67} & 9.98 & \multirow{2}{*}{2.009} \\
\cline { 1 - 3 } Control & 26 & 62.54 & & & \\
\hline
\end{tabular}

From the table above, it can be seen that t-value is higher than $\mathrm{t}$ - table of .05 with the degree of freedom (df) of $50(26+26-2)$. It means that there is a significant difference of post-test between experimental and control group. 
The significant difference mean scores between pre-test and post-test scores of the experimental group

To know the significant difference mean scores of the pre-test and post- test of the experimental group, the researcher made a table difference mean score. The researcher got the result of pre-test and post-test of the experimental group was 59.42 and 89.19. After calculating the difference of pre-test and post-test, then the researcher calculated the significant difference by using t-test formula score. The table below shows the result of the calculation.

Table 5

Significant Differences of Pre-test and Post-test Scores of the Experimental Group

\begin{tabular}{|c|c|c|c|c|c|}
\hline \multirow{2}{*}{ Group } & \multirow{2}{*}{$\mathbf{N}$} & \multicolumn{2}{|c|}{ Mean } & \multirow{2}{*}{$\begin{array}{l}\text { t- } \\
\text { value }\end{array}$} & \multirow{2}{*}{ t-tabl } \\
\hline & & Pre-test & Post-test & & \\
\hline $\begin{array}{l}\text { Experimenta } \\
1\end{array}$ & 26 & 59.42 & 89.19 & 13.35 & 2.060 \\
\hline
\end{tabular}

From the data above, it can be seen that the $t$-value is higher than $t$ - table. So, it can be concluded that there is significant difference between pre-test and post-test of experimental group.

The significant difference mean scores between pre-test and post-test scores of the control group

To know the significance difference mean scores of the pre-test post-test of the control group, the researcher made a table difference mean score. After got the mean score of both pre-test and post- test, the researcher calculated the t-value by using t-test. Below is the table that shows the result of the calculation.

Table 4.6

Significant Differences of Pre-test and Post-test Scores of the Control Group

\begin{tabular}{|c|r|r|r|r|r|}
\hline \multirow{2}{*}{ Group } & \multirow{2}{*}{$\mathbf{N}$} & \multicolumn{2}{|c|}{ Mean } & \multirow{2}{*}{ t-value } & t-table \\
\cline { 3 - 5 } & $\begin{array}{c}\text { Pre- } \\
\text { tect }\end{array}$ & Post-test & & \\
\hline Control & 26 & 60.96 & 62.54 & 1.93 & 2.060 \\
\hline
\end{tabular}


By taking a look at the table above, it can be seen that the $\mathrm{t}$-value is lower than $\mathrm{t}$ table. So, it can be concluded that there is no significant difference between pre-test and post-test of control group.

\section{The Significant Difference of Pre-test and Post-test Scores of the Experimental and Control Group}

To analyze the significant difference between pre-test and post-test of the experimental and control group, the researcher computed the data from the result score of the pre-test and post-test of both experimental and control group. To calculate tvalue of the pre-test and post-test of both experimental and control group, the researcher used the following steps:

1. Making a list of pre-test and post-test of both experimental and control group

2. Calculating the data by using t-test formula

3. Comparing the t-value and the t-table with 50 degree of freedom and level of significance .05

Table 7

The Significant Differences between Pre-test and Post-test Scores of the

\section{Experimental and Control Group}

\begin{tabular}{|c|c|c|c|c|c|c|}
\hline \multirow{2}{*}{ Group } & \multirow{2}{*}{$\mathbf{N}$} & \multicolumn{2}{|c|}{ Mean } & \multirow{2}{*}{$\begin{array}{c}\text { t- } \\
\text { valu } \\
\text { e }\end{array}$} & t.05 & Significance \\
\cline { 3 - 5 } & & $\begin{array}{c}\text { Pre- } \\
\text { test }\end{array}$ & $\begin{array}{l}\text { Post } \\
\text { - test }\end{array}$ & ean & \\
\hline Experimental & 26 & 59.42 & 89.19 & 10.93 & 2.009 & Significant \\
\cline { 1 - 4 } Control & 26 & 60.96 & 62.54 & & & \\
\hline
\end{tabular}

Table 7 above shows the pre-test and post-test of both experimental and control group and also the t-value of the difference. From the table, the result of the pre-test in experimental group was 59.42 and the result of the pre-test in control group was 60.96 . The table also shows the result of the post-test in experimental and control group was 89.19 and 62.54. Besides that, the table proves that $t$-value of pre-test and post-test of both experimental and control group is higher than t-table with 50 degree of freedom and level of significance .05

Since the t-value of pre-test and post-test of both experimental and control group is higher than t-table, it can be concluded that there is a significance difference between the eighth graders who were taught using $T R G$ and those who were not. 


\section{Hypothesis Testing}

In the previous chapter, it was explained that the aim of this study attempts to find out whether there is a significant difference in scores of grammar simple past tense test between the eighth graders who are taught using teacher races game and those who are not taught in that way. There are two hypotheses in this tudey; null hypotheses (Ho) and alternative hypothesis (Ha). In this case, to test the hypotheses, the researcher used t-test formula. If the result of the calculation found that $t$-value is higher than $t$-table, it means that the null hypothesis is rejected and alternative hypothesis is accepted. On the other hand, if the result of the calculation found that $t$-value is lower than ttable, it means that the null hypothesis is accepted and the alternative hypothesis is rejected. To know the more result of the analysis of the hypothesis.

\begin{tabular}{|c|c|c|c|}
\hline $\begin{array}{c}\text { Df (Degree } \\
\text { of freedom) }\end{array}$ & t-value & $\mathbf{t}_{\mathbf{0} 5}$ & \multicolumn{1}{c|}{ Explanation } \\
\hline 50 & 10.9 & 2.009 & $\begin{array}{l}\text { Alternative hypothesis (Ha) is } \\
\text { accepted } \\
\text { Null hypothesis (Ho) is } \\
\text { rejected }\end{array}$ \\
$\begin{array}{l}\mathrm{t}_{\text {value }} \\
\left.\mathrm{t}_{\text {table }} \text { is higher } 10.93>2.009\right) \\
\text { Therefore: }\end{array}$ \\
\hline
\end{tabular}

\section{DISCUSSION}

This research focused on the eighth graders' grammar simple past tense; since simple past tense grammar is one of the language features of recount text that have to be mastered by the eighth graders (Priyana, Irjayanti, \& Renitasari, 2008, p. 69). Due to mastering simple past tense, the students are expected to be able to construct the sentences in the form of recount text.

Thus, this study attempts to find out whether there is a significant difference in scores of grammar simple past tense test between the eighth graders who are taught using $T R G$ and those who are not taught in that way. From the result taken by the researcher, it presents those students who were taught using teacher races game got higher score than the students who were not taught using that way. The result score of pre-test and posttest of both groups could be noticed in the table below. 


\begin{tabular}{|c|c|c|}
\hline & Experimental Group & Control Group \\
\hline Pre-test mean & 59.42 & 89.19 \\
\hline Post-test mean & 60.96 & 62.54 \\
\hline$t_{\text {value }}$ & \multirow{4}{*}{\multicolumn{2}{|c|}{$\begin{array}{c}10.93 \\
2.009 \\
\mathrm{~T}_{\text {value }}>\mathrm{t}_{\text {table }} \\
\text { Significant }\end{array}$}} \\
\hline t.005 & & \\
\hline Result & & \\
\hline Significance & & \\
\hline
\end{tabular}

The table above showed the post-test mean of experimental group is 89.19 , while control group is 62.54. After those scores are calculated using t-test with level of significance .05 , the result of t-value is 10.93 , on the other hand the t-table is 2.009 . It means that $\mathrm{t}$-value is higher than $\mathrm{t}$-table. Since the $\mathrm{t}$-value is higher than $\mathrm{t}$-table, it can be concluded that the Alternative Hypothesis is accepted. Thus, the TRG was effective to improve students' grammar simple past tense mastery.

$T R G$ was an effective game to teach simple past tense to improve grammar simple past tense mastery. It helps students to mastery grammar simple past tense which also helps them to compose in writing recount texts. The reason why teacher races game could improve the eighth grammar mastery is very interesting to be investigated. First, according to Brown (2001) when the student are asked to move around, to dictate the wrong sentence into the right one to their teacher, help them to keep on their physically active. Their motoric activity did more and makes them did not get bored at all.

As we know, through the motoric activity, the students are going to memorize easily about the whole learning process (Brown, 2001). They will remember what the lesson about longer. As a result, the researcher decided to choose this technique to teach simple past tense, because teacher races game fulfill motor activity which can motivate students to learn in language learning process. On the other hand, the control group was also get higher score in post-test than in pre-test but the progression is not as good as in experimental group. This result happened because control group did not get special treatment. They seem really bored with conventional way as it did not support their motoric activity.

Comparing the result of pre-test and post-test in experimental group, we can see that the students' score grammar simple past tense had not been improved yet while in pre-test. They still got difficulties to use simple past tense in a sentence. For the example, the students still feel very difficult when they want to differentiate between verbal sentence and non verbal sentence and how they put the correct 'tobe' which is appropriate with the subject. Moreover, they also get obstacle when they want to change the verb base into v2 in irregular verb. However, after they got three times treatments, the students' score grammar simple past tense increased since they have learned how put the right 'tobe' in non verbal sentence related to the subject in the sentence; and how they change the verb base into v2 in irregular verb. This process could be happened because in process learning using teacher races game, the student are asked to move around, to dictate the wrong sentence into the right one to their teacher, help them to keep on their physically active. Their motoric activity did more and makes them did not get bored at all. They are 'forced' to memorize the pattern and how to use grammar 
simple past tense properly. However, compared with the result to the control group's score simple past tense in control group were not improved as in experimental group.

As same as in experimental group result, we can see that the students' grammar mastery in control group also had not been improved yet while in pre- test. They found obstacles to use simple past tense in a sentence. For instance, the students still felt very difficult when they want to differentiate between verbal sentence and non verbal sentence and how they put the correct 'tobe' which is appropriate with the subject. In addition, they also get obstacle when they want to change the verb base into v2 in irregular verb. However, as the control group was

also got the same material such as experimental group, in the post-test, the control score were also improved.

Considering that the students in control group were not introduced with teacher races game, their ability in control group is still lack if compared with the experimental group. It could be happened because in process learning, they do not get special treatment. They are not taught using teacher races game. They are not asked to move around, dictate repetition the wrong sentence into the right one to their teacher. Therefore, their motoric activity did not explore much makes them get bored. They are not 'forced' to memorize the pattern and how to use grammar simple past tense properly.

Overall, from the all result stated above, we can conclude that there are some advantages of Teacher Races Game. Teacher Races Game provided the researcher an effective cooperative game which let pupil how to work cooperatively in a group, where they must learn about dividing job and take responsibilities (Smith, 2006). Moreover, through this game, we also let their motoric skill being more active, all of the students in the class can be active in learning process. Thus, the use of this game can be an alternative technique in helping the teachers to encourage the students' writing ability and the students will enjoy teaching learning process. Games are really an attractive way because they are fun; the pleasant relaxed atmosphere fostered by games has proven to be efficient learning (Johnson and Johnson, 1975: 75).

\section{CONCLUSION}

This research attempts to find out whether there is a significant difference in scores of grammar mastery - simple past tense between the eighth graders who are taught using teacher races game and those who are not taught in that way. From the pretest that has been conducted in both experimental and control group can be seen that the ability of the both of group were equal. It was proved by the calculation, the $t_{\text {value }}$ on $\mathrm{df} 50$ was -0.51 , and at t.005 was 2.009. Hence, the $t_{v a l u e}$ is $<$ than table. So, the result was not significant.

After gave treatment, post test was administered to find out whether there is a significance difference between students who are taught using TRG and those who are not taught in that way. From the post test score, the pupils in experimental class got higher scores than pupils in control class. It can be proved with the result of $t_{\text {value. The }} t_{\text {value }}$ of post test was 9.98 then to imply the stastical significance of it, the researcher used table in basic stastical concepts table. From the basic stastical concepts table the critical value of $t$ at 0.05 level of significance with d.f (degree of freedom ) 50 is 2.009. From the calculation

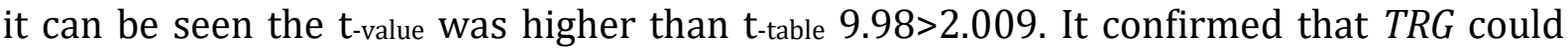


improve the students' ability in mastering simple past tense grammar. The hypothesis was accepted as the $t_{\text {value }}$ was higher than $t_{\text {table. }}$

\section{REFERENCES}

Anderson, M. and K. Anderson. (1998). Text Type in English 3. South Yara: Mac Millan Education Australia PTYLTD.

Arikunto, Suharsini. (2006). Prosedur Penelitian Suatu Pendekatan Praktik. Jakarta: Rineka Cipta.

Ary, D, Jacobs, L. L. C., et al. (1990). Introduction to Research in Education. Florida: Harcourt Brace College Publishers.

Brown. (2001). Teaching by Principles. San Fransisco State University: Longman.

Departemen Pendidikan Nasional. (2006). Standar Isi dan Standar Kompetensi Kelulusan: Mata Pelajaran Bahasa Inggris. Jakarta: Depdiknas.

Ersoz, Aydan. (2002). Six Games for The EFL/ESL Classroom. The Internet TESL Journal, Vol. VI, No. 6 June.

Hadfield, J. (2005). Intermediate Writing Communication Games. England: Longman.

Harmer, J. (2003). The Practice of English Language Teaching. England: Longman.

Heaton, J.B. 1974. Writing English Language Tests. Longman: Longman Group Limited.

Johnson, David W and Roger T. Johnson. (1975). Learning Together and Alone: Cooperation, Competitive and Individualization. New Jersey. Prentice Hall Inc. Englewood Cliffs.

Kim, Lee Su. (1995). Creative Games for Language Classes. English Teaching Forum Vol. XXXIII No. 1 January.

Mc Millan, James H. and Sally Schumacher. (1993). Research in Education: A Conceptual Introduction $2^{\text {nd }}$ Edition. New York: Harper Collins College Publisher.

Priyana, Irjayanti, and Renitasari. (2008). Scaffolding: English for Junior High School Students Grade VIII. Surabaya: PT JePe Press Media Utama (Jawa Pos Group).

Richard, J. and Theodore S.R. (1987). Approaches and Methods in Language Teaching. America: Cambridge University Press.

Richard, Jack C et al. (2002). Methodology in Language Teaching. Cambridge: Cambridge University Press.

Santrock, J. W. (1993). Life-Span Development First Edition. Jakarta: Erlangga.

Smith, Helen. (2008). British Council 'Running Dictation'. It is retrieved from (http://www.Britishcouncil.org/flashonline-lessons-all-ages-runningdictation.doc)

Wright, Andrew. Batteridge D, Buckby M. (1983). Games for Language Learning. New York: Cambridge University Press. 